\title{
Remote Sensing and GIS Application on Forest Resource Mapping and Monitoring in Bulolo District, Morobe Province
}

\author{
Wilson Kumne*, Sailesh Samanta\# \\ Department of Surveying and Land Studies, GIS Section, Papua New Guinea University of Technology, Lae, PNG \\ Email: wilsonkumne947@gmail.com, "rsgis.sailesh@gmail.com
}

How to cite this paper: Kumne, W., \& Samanta, S. (2019). Remote Sensing and GIS Application on Forest Resource Mapping and Monitoring in Bulolo District, Morobe Province. Journal of Geoscience and Environment Protection, 7, 37-48. https://doi.org/10.4236/gep.2019.72003

Received: January 12, 2019

Accepted: February 12, 2019

Published: February 15, 2019

Copyright (c) 2019 by author(s) and Scientific Research Publishing Inc. This work is licensed under the Creative Commons Attribution International License (CC BY 4.0).

http://creativecommons.org/licenses/by/4.0/

\begin{abstract}
Forest resources monitoring are particularly challenging for tropical forest due to their diverse composition and structure and a wide range of stakeholder's expectations and requirement. New monitoring approaches and control policies directions are required to meet these different challenges. For the past decades, much of the focus of formal forest monitoring and management policy in Papua New Guinea (PNG) has been on large scale conventional harvesting to meet national requirements for economic development, with little attention given to community or small area forest management and monitoring. The current management is considered to be unsustainable and, as forest resources from primary forests are exhausted. This has resulted in extensive cutover forest areas being left to degrade over time. Forest reserve has suffered seriously and if the present trend of deforestation continues; it is just a matter of time when the whole reserve would have been converted to a bare ground. This study therefore examined the integration of remote sensing (RS) and geographic information system (GIS) application on forest resource mapping and monitoring in Bulolo district, Morobe province. Landsat satellite imageries for 1992, 2002 and 2014 were used to classify and identify forest changes through change detection techniques. A GIS database of land use categories and their location within 24 years (1992-2014) were generated and analysed with the aid of GIS analytical functions. This function includes area calculation, overlay, and image differencing, supervised classifications, cross tabulations and map representation. The result shows that population growth (anthropogenic) factors among communities around the natural forest imposes a lot of pressure on the natural forest resources. This should also include consideration of the future usage capacity of the forest resources as well as development of the capacity of local forest owner communities to participate in small scale forest management and utilization.
\end{abstract}




\section{Keywords}

Remote Sensing, GIS, Land Use and Land Cover Classification, Forest Change

\section{Introduction}

Forests are important renewable resources and it plays important role, which is suitable for human life. The forests of Papua New Guinea (PNG) make a critical contribution to the economic, social and environmental well-being of the nation. However, these forests are under serious threat from deforestation and from effects on soil, water and biodiversity resulting from unsustainable forms of human activities and others. Papua New Guinea contains approximately half of the third largest extant area of tropical rain forest in the world, and is one of the most bio-diverse and ecologically distinct forested regions. Pressures on forest in PNG to provide economic resources and personal benefits have been increasing rapidly as a consequence of growing population in the region (Ningal et al., 2008). This has led to a forceful deforestation, which has been recognized as one of the major drivers of biodiversity loss as well as a threat to ecology. Tropical forests in Bulolo area of Morobe province are undergoing wide-scale degradation; therefore it is documented here by the use of remote sensing data to monitor and to rescue the forest. Exploitation of these forest resources takes place consistently for various purposes which vary from commercial to non-commercial, need for space in road construction, firewood harvesting, construction of residential building, sand excavation, subsistence agriculture, forestry, fire, plantation development and mining has all driven deforestation in PNG. Forest degradation has also occurred, largely as the result of conversion of primary forest into secondary forest by commercial logging (Bryan et al., 2010).

Papua New Guinea land has 33 Mha of forested land out of the 46.28 Mha of land mass. It has seen that the 33 Mha forested land is productive and have the potential to satisfy the needs of the people economically as well as to sustain day to day living of the native land owners. PNGFA have seen the potential in the forest resource in some of forest development. The rich of forest resource in PNG is now becoming the long-term national asset. The vegetation and forest types that we have in the country have been discussed in detail (Paijmans, 1976; Hammermaster \& Saunders, 1995). Papua New Guinea's wide range of floristic composition is a characteristic of the lowland tropical forests. Forest cover in PNG declined at an estimated annual rate of 113,000 ha (0.4\%) between 1990 and 2000 (FAO, 2005). At the national level, 4.1\% of forests were either cleared or logged over the 12 year period. This suggests a reduction in the rate of change that was found in the period between 1972 and 2002 (Shearman et al., 2008). Much of the change in this earlier period occurred in the latter years of those decades, at an estimated annual rate of deforestation and forest degradation of 
1.4\% between 2001 and 2002 (Shearman et al., 2009). In contrast, the estimated annual rate of deforestation and degradation for 2013-2014 was 0.49\%. From 2002 statistics, PNGFA estimated that the untouched forest of PNG was 29.7 Mha while the harvested land area comprised 3.4 Mha (PNGFA, 2004; Fox et al., 2010). It has seen that more than half of the forested and was being exploited by timber harvesting. Now we will conclude that that this part of forest resources is seen degraded and the timber industry assumed that it has no current potential for timber production. In the Momase region alone, 500,000 ha of the forested area were being exploited.

Forest destruction in PNG begins when timber were being harvested from the natural forest during the second world war for military purposes. After several years from the war period forestry activities restarted and were mainly to concentrate on producing timbers for post-war reconstruction and building. Early timber harvest for commercial begins in the 1950s (Lamb, 1990) in the Bulolo area. There a ply mill was established to process logs from natural forest timbers. A world bank reports states that extensive forest resources in PNG that warranted large scale commercial exploitation (Lamb, 1990). Following the report, large timber areas were offered for sale in public tender and so there were increased number of timber areas allocated for harvesting all throughout PNG under the timber rights purchase (TRP) arrangements. Some of those areas were Bougainville, Gogol valley in Madang and Bulolo area in Morobe. In 1968 a called was made to increase the production and processing of timber all through the country by the PNG administration. With the call made by the PNG administration large companies like Japan and New Guinea Timbers (JANT) came in doing extensive timber harvesting doing clear cut forest harvest. With those increasing timber processing, our natural forest began to lose its form. In 1980 Australian companies came in to harvest in some parts of PNG, and from 1980s to 1990 s there have been large timber harvesting lamb 1990 in our primary natural forest by those foreign companies (Shearman et al., 2008). In this short history of forest exploitation shows that the primary forests in PNG is under great pressure from industry, and the areas of cutover forests in rapidly increasing. This means that PNG is losing the primary forest at a faster rate and timber harvesting is the major contributing factor to the exploitation of the primary forest. In last few decade GIS and RS technologies are being used for environmental and forest planning and monitoring. Use of recent technologies, like RS and GIS were not implemented by researcher of Papua New Guinea for forest resources monitoring and management. Today foresters in Papua New Guinea have seen GIS and RS technologies as the powerful and useful tools for record keeping and analysis and decision making. The primary aim of this project is to do forest resource mapping and monitor the usage of the natural forest Resource with the aid of RS and GIS Technology to preserve natural primary forest. In these recent years GIS and RS are becoming popular technological tools for continuous forest resource monitoring. Since forest deals with different objective from a single 
patch of forest (e.g. forest monitoring and planning), a wider variety of spatial information is required and sources of reliable data are needed for developing a GIS in forest monitoring and management.

\section{Study Area and Materials}

Bulolo is one of the nine districts of Morobe province of Papua New Guinea. It is located $43 \mathrm{~km}$ (27 miles) south of Lae and $32 \mathrm{~km}$ (20 miles) north-east of Wau. It is located $7^{\circ} 12^{\prime} 0 " \mathrm{~S} 146^{\circ} 38^{\prime} 48^{\prime \prime} \mathrm{E}$ within Papua New Guinea with the elevation of $700 \mathrm{~m}$ (2300 ft.) above sea level (Figure 1). The major economic factor in Bulolo area is the forest industries, with the PNG forest products limited the main enterprise. Recently mining boom in Bulolo has become the major economic factor in the district which invites a lot of people to Bulolo to do business.

Enhanced sensor instrumentations like thematic Mmpper (TM) in landsat 5, enhanced thematic mapper plus (ETM+) in Landsat 7 and operational land imager (OLI) in Landsat-8 are designed to monitor medium-scale features on the Earth's surface. Three satellite images for different years, namely Landsat 5, TM image of 1992, Landsat 7 EMT+ image of 2002 and Landsat 8 OLI image of 2014 with $30 \mathrm{~m}$ spatial resolution were used for this study as primary data sets (Table 1). Other supporting data like topographic maps, economic, historical, demographic data etc. were also used were collected from PNG's national database (PNGRIS, 2008).

\section{Methods}

Different methods of digital image processing were successfully implemented (Jensen, 1996) to achieve the objective of this research. Geo-referencing was

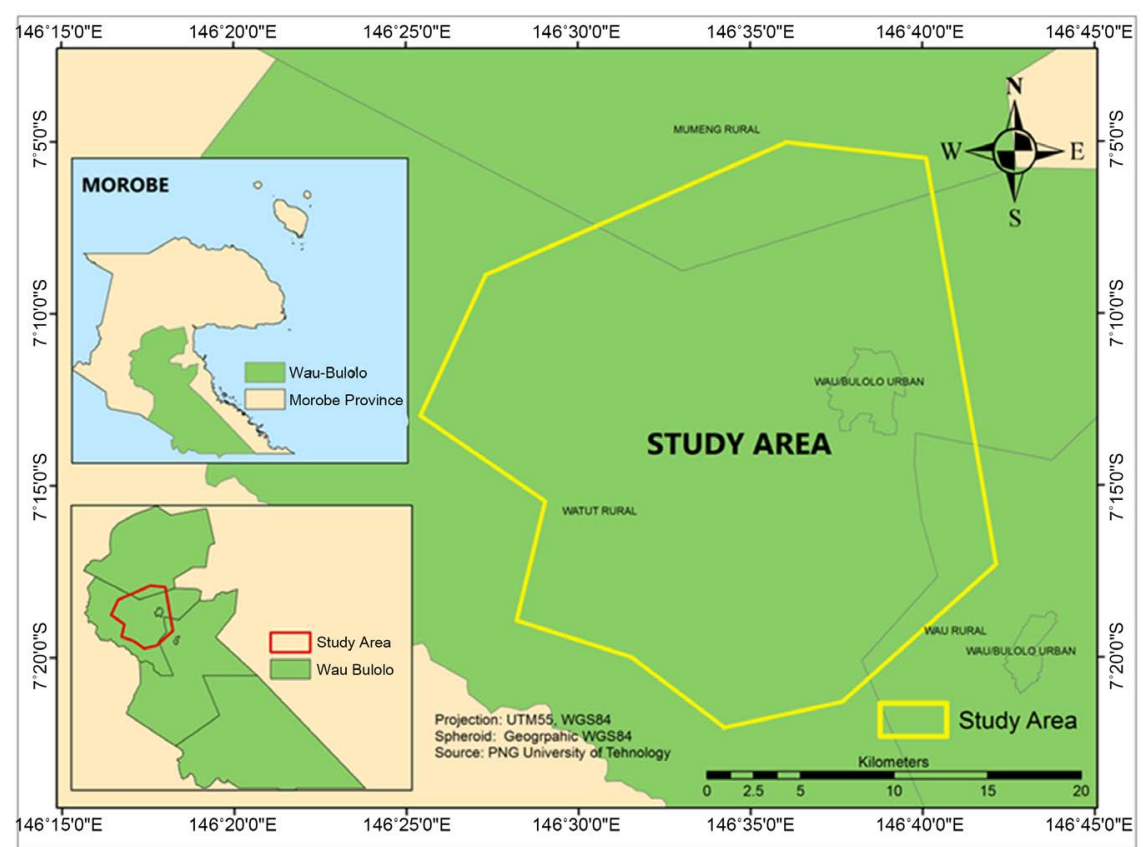

Figure 1. Location map of the Study area. 
Table 1. Landsat satellite specification used for the study.

\begin{tabular}{ccccc}
\hline Year & Satellite & $\begin{array}{c}\text { Standard False Colour } \\
\text { Composite Bands }\end{array}$ & $\begin{array}{c}\text { Bands for visual } \\
\text { interpretation }\end{array}$ & Pixel size \\
\hline 1992 & Landsat 5 TM & $4,3,2$ & $4,5,3$ & $30 \mathrm{~m}$ \\
2002 & Landsat 7 ETM+ & $4,3,2$ & $4,5,3$ & $30 \mathrm{~m}$ \\
2014 & Landsat 8 OLI & $5,4,2$ & $5,6,4$ & $30 \mathrm{~m}$ \\
\hline
\end{tabular}

done at an accuracy of $12.7 \mathrm{~m}$ on a map scale of 1:50,000. The projection system used was Universal Transverse Mercator (UTM), Zone 55 South on World Grid System 1984 (WGS84) Datum in metric units (Yali et al., 2015). Methods are broken into three parts: preparation, interpretation and analysis (Figure 2).

All three images from 1992 to 2013 were enhanced manually by applying brightness/contrast tool in Erdas imagine to improve the illumination of pixels. The enhanced images were then saved as new images with new file names. After performing brightness and contrasting the images were allocated bands 4-5-3 (R-G-B) for landsat 5 and 7 images while landsat 8 was allocated band composition of 5-6-4. This band arrangement was set to conduct "training sets" creation for signature file creation using visual interpretation (Lillesand et al., 2008). Level 1 or the generic class descriptions are based on the united state geological survey (USGS) five (5) land use categories: dense or primary forest, secondary forest, grassland, built-up and water body. The target class was forest class. A supervised (full Gaussian) maximum likelihood classification was implemented (Samanta et al., 2012) for the three images and the final classification products provide an overview of the major land use/land cover features of Bulolo forest area for the year 1992, 2002, 2014.

Post-classification or reassessment of a classed image is performed to refine the classified image. Year 1992 was used as the base map. The classified image for year 1992 further applied for recoding and GIS analysis tasks in Erdas Imagine. Recoding is the task of changing the values of a class of pixels to a new value. This is only applicable for thematic raster data. For this task, the recoding from attribute table was used to update the misclassified areas observed on the initial accuracy assessment. Accuracy assessment was performed by comparing the map created by remote sensing analysis to a reference map based on a different information source. One of the primary purposes of accuracy assessment and error analysis in this case is to permit quantitative comparisons of different interpretations.

\section{Results and Discussion}

The assessment completes the process of validating the classification, although the classification is not $100 \%$ perfect. On the other hand, there are uncertainties associated with the extent of each class in hectares. Addressing uncertainty requires a separate analysis to assess how confident the data is by determining the threshold above and below the actual areas in hectares of the forest types. Accuracy 


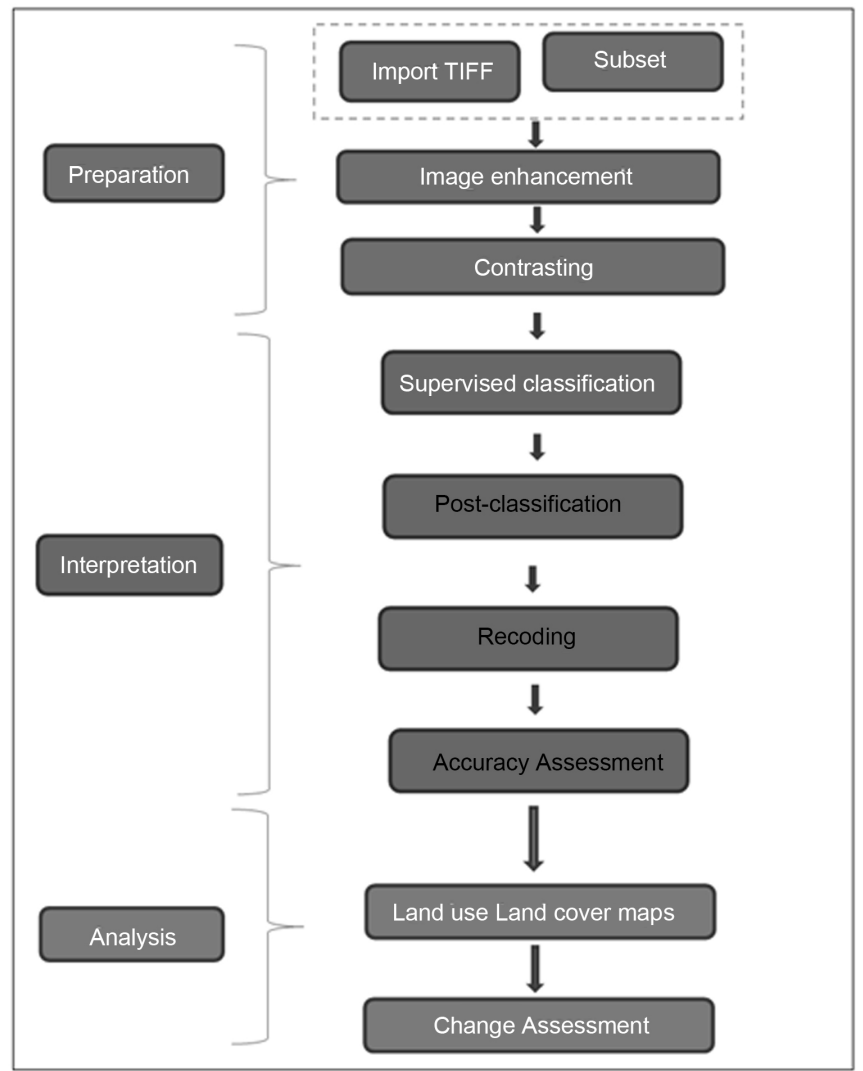

Figure 2. Workflow chart showing the various stages of processing in an image analysis stage.

totals and kappa statistics were generated separately for each year and each class. Before post-classification was applied the level of accuracy was very low. Upon conducting the accuracy assessment after the post-classification, all the thematic maps were above the required accuracy total cut-off mark 85\% and Kappa statistics required agreement minimum of 0.4. Table 2 presents details of class wise accuracy assessment report for each classification from 1992-2014. Overall accuracy and kappa statistics of the classification were calculated as $88.24 \%$ and 0.8267 for year $1992,90.00 \%$ and 0.8413 for year 2002 and $88.00 \%$ and 0.7930 for year 2014 respectively (Table 2 ).

The classified maps were framed and decorated with legends, scale, grid etc. to make the users easy interpretable. These final outcomes of the map will help communities, foresters, managers and planners to fully understand the forest types and their exact location. A total of three classified thematic raster maps were produced for 1992, 2002, and 2014 (Figure 3).

Five major classes were identified and classified using satellite images of three different years (1992, 200 and 2014). These images were classified to generate land use/land cover of all the five classes as follows: dense primary forest, secondary forest, grassland areas, build-up area and water body. However, amongst these five major classes, three classes were identified as the major impact classes that is heavily do with forest changes; dense primary forest i.e. the untouched 
Table 2. Accuracy assessment results for accuracy totals and kappa statistics for 1995-2015.

\begin{tabular}{|c|c|c|c|c|}
\hline \multirow{2}{*}{ Sl. No. } & \multirow{2}{*}{ Class Name } & \multicolumn{2}{|c|}{ Accuracy Totals } & \multirow{2}{*}{ Overall Kappa } \\
\hline & & Producers Accuracy & Users Accuracy & \\
\hline \multicolumn{5}{|c|}{ Year-1992 } \\
\hline 1 & Dense primary forest & $90.00 \%$ & $94.74 \%$ & \\
\hline 2 & Secondary forest & $69.23 \%$ & $90.00 \%$ & \\
\hline 3 & Grassland & $100.00 \%$ & $80.00 \%$ & 0.8268 \\
\hline 4 & Built-up & $100.00 \%$ & $100.00 \%$ & \\
\hline 5 & Water/river & $100.00 \%$ & $100.00 \%$ & \\
\hline \multicolumn{5}{|c|}{ Overall Accuracy: $88.24 \%$} \\
\hline \multicolumn{5}{|c|}{ Year-2002 } \\
\hline 1 & Dense primary forest & $100.00 \%$ & $100.00 \%$ & \\
\hline 2 & Secondary forest & $88.00 \%$ & $91.67 \%$ & \\
\hline 3 & Grassland & $83.33 \%$ & $76.92 \%$ & 0.8413 \\
\hline 4 & Built-up & $100.00 \%$ & $100.00 \%$ & \\
\hline 5 & Water/river & $100.00 \%$ & $100.00 \%$ & \\
\hline \multicolumn{5}{|c|}{ Overall Accuracy: 90.00\% } \\
\hline \multicolumn{5}{|c|}{ Year-2014 } \\
\hline 1 & Dense primary forest & $85.71 \%$ & $100.00 \%$ & \\
\hline 2 & Secondary forest & $90.00 \%$ & $96.43 \%$ & \\
\hline 3 & Grassland & $83.33 \%$ & $71.43 \%$ & 0.7930 \\
\hline 4 & Built-up & $100.00 \%$ & $100.00 \%$ & \\
\hline 5 & Water/river & $100.00 \%$ & $100.00 \%$ & \\
\hline \multicolumn{5}{|c|}{ Overall Accuracy: $88.00 \%$} \\
\hline
\end{tabular}

forest. After the satisfaction on accuracy and kappa statistics area covering by each land use/land cover were calculated and tabulated for future comparison. A change detection technique was used to find changes of land use/land cover (Samanta \& Pal, 2016) in the study area during 1992 to 2014. In the year 1992 the dense primary forest cover was $34.48 \%$, whereas it was $20.78 \%$ in 2002 , and $11.41 \%$ in 2014 respectively (Figure 3 ). The trend is that the primary dense forest resource in Bulolo area is decreasing. The dense primary forest depleted alone account for more than $13.7 \%$ in the year 2002 and $9.37 \%$ in the year 2014 while secondary forest, i.e. the pine forest plantation account for more than $11.72 \%$ increase in 2002 and $7.83 \%$ increase in year 2014, grassland account for more the $1.72 \%$ increase in the year 2002 and a $1.15 \%$ decrease in the year 2014 (Figure 4 and Table 3). Activities that were leading to degradation of the natural forest are called deforestation. It was discovered that there is a large decrease of dense primary forest between 1992 (22,595.9 hectares or 34.48\%) and 2014 $(13,623.7$ hectares or $20.78 \%)$, indicated a total loss of 12363.5 hectares or $23.07 \%$. 


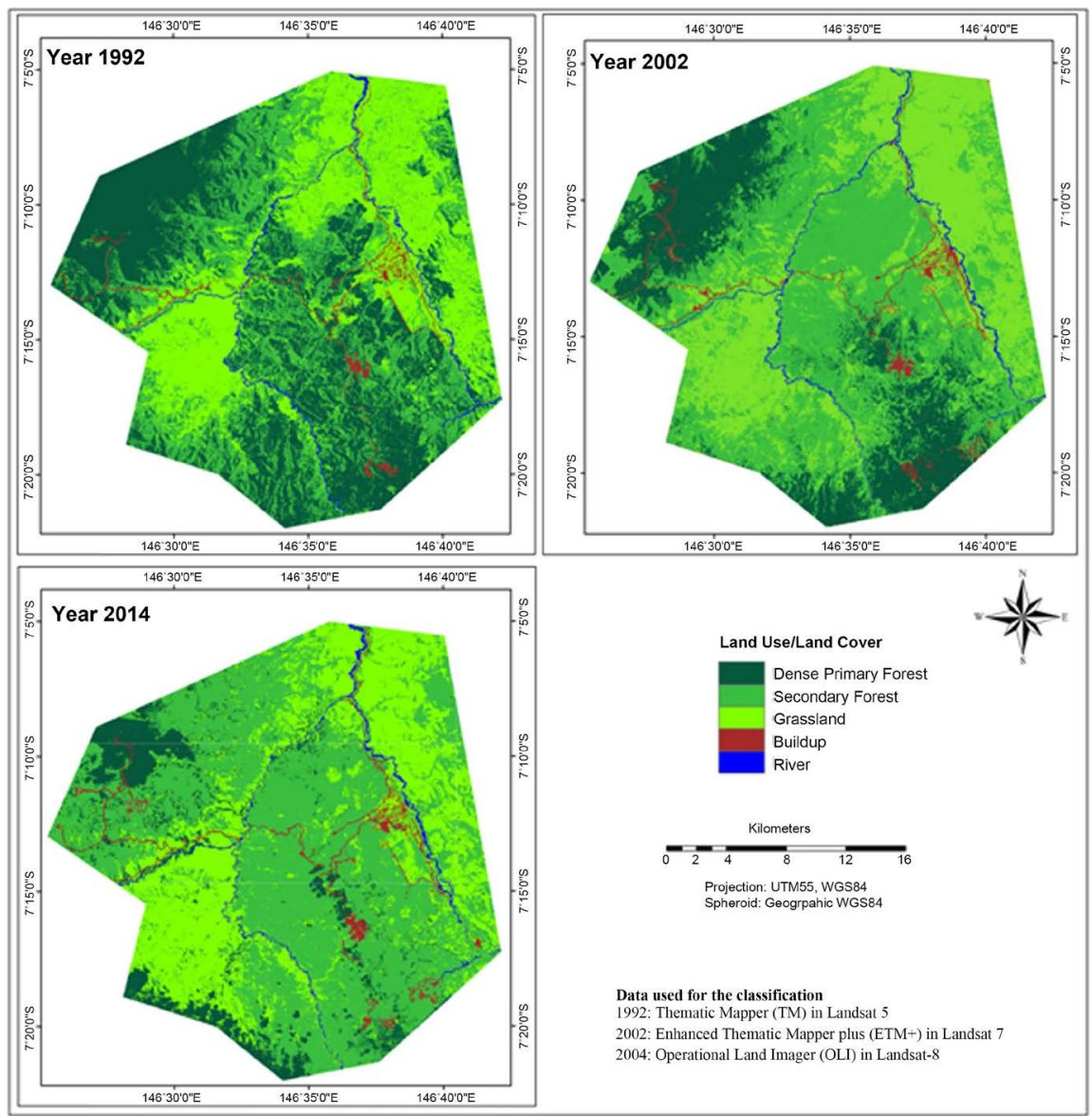

Figure 3. Classified land use and land cover maps of the study area (1992-2014).

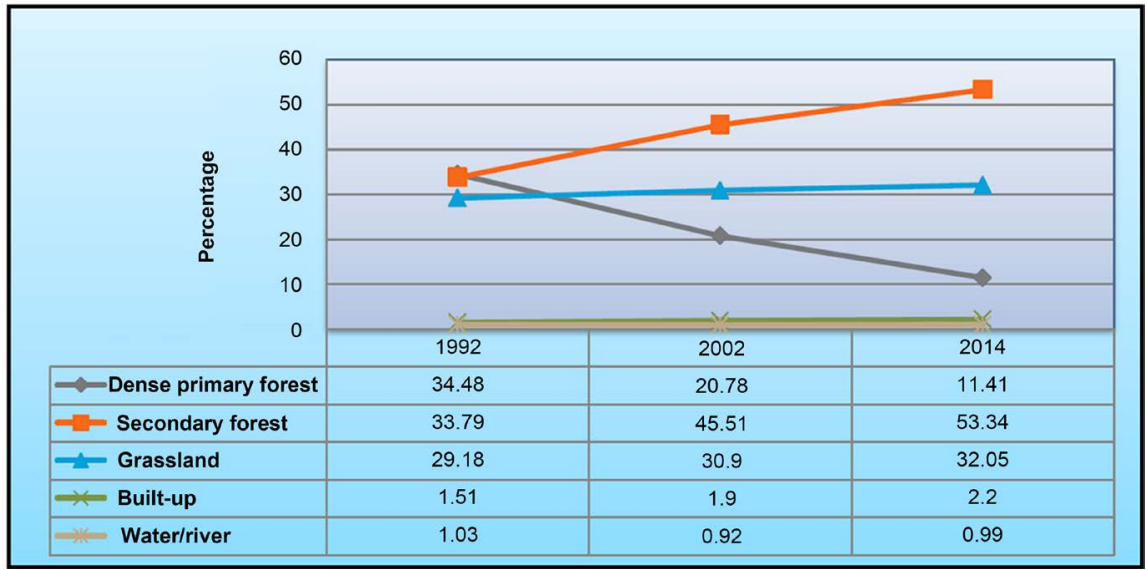

Figure 4. Land use land cover changes between 1992 and 2014.

This is as a result of dense primary forest classes being converted to forest plantation, logging, developments and agricultural activities.

There was a tremendous increase in secondary forest from 1992 to year 2002 i.e. from 22,595.9 hectares of land in 1992 to 13,623.7 hectares in 2002 to 7480.71 hectares in year 2014 (Table 3). This is due to the loss of dense primary forest. The dense primary forests are being converted by logging and those lands after 
Table 3. Land use/Land cover Distribution during 1992 to 2014.

\begin{tabular}{cccccccc}
\hline \multirow{2}{*}{ Sl. No. } & Land use/land cover & \multicolumn{2}{c}{1992} & \multicolumn{2}{c}{2002} & \multicolumn{2}{c}{2014} \\
\cline { 3 - 8 } & & Area (ha) & Area (\%) & Area (ha) & Area (\%) & Area (ha) & Area (\%) \\
\hline 1 & Dense primary forest & 22595.9 & 34.48 & 13623.7 & 20.78 & 7480.71 & 11.41 \\
2 & Secondary Forest & 22139.3 & 33.79 & 29842.9 & 45.51 & 34952.7 & 53.34 \\
3 & Grassland & 19122.8 & 29.18 & 20262.1 & 30.9 & 21002.5 & 32.05 \\
4 & Built-up & 992.25 & 1.51 & 1244.94 & 1.9 & 1439.46 & 2.2 \\
5 & Water/River & 674.55 & 1.03 & 602.6 & 0.92 & 649.53 & 0.99 \\
\hline
\end{tabular}

logging was again converted to pine plantation for commercial purpose and some land were left barren in which grass land took over, then gradually to shrubs. Grass land class increase from 19122.8 hectares in 1992 to 20262.1 hectares in 2002 and a slide decrease to 21002.5 in the year 2014 (Table 3).

There is increase in grassland due pine being harvested and bare land been set on fire which turns to grassland. Build up area slightly increase due to land developments. It was found that secondary forest, grassland and build up increased in size from 1992 to 2014 ( 22 years) i.e. dense forest were being converted to secondary forest and grassland then to build up. Buildings and roads were constructed to increase the buildup area and at the same period of time logging of dense primary forest and conversion of land to pine forest and other forces on the dense primary forest were on the increase and dense primary forest size which decrease as a result. Figure 5 shows the preview of image differencing; a method of change detection was carried out with two pairs of satellite data, i.e. 1992-2002 and 2002-2014. The results indicates unchanged area in black and change area in green (10\% increase) and red (10\% decrease).

The annual rate of increase of secondary forest, grassland area and buildup were on the positive 1.67, 0.45 and 2.05 percent whereas the annual rate of decrease of dense primary forest was on the negative -3.04 percent (Table 4). In 1992 dense primary forest occupied 34.48 percent of the total land area as a result of a prior logging and conversion of dense primary forest and other activities it decreases to 11.41 percent in the year 2014 (Table 4).

\section{Conclusion and Recommendations}

A total of five (5) land use and land cover types were mapped using landsat satellite imagery using supervised classification. The classified maps went through post-classification in which the accuracy assessment results were further improved compared to the initial classification. Dense primary forest degradation rate of $3.04 \%$ is greatly affected by the deforested areas that are used for logging roads. The outlook for the natural forest resources and the forestry sector in $\mathrm{Bu}$ lolo is one in which the sector will continue to grow in importance and provide for the economic and social well-being of the people. A better future can be created for the people of Bulolo area and PNG, where the natural forests can be 
Table 4. Rate of Land Use/Land Cover changes during 1992 to 2014.

\begin{tabular}{|c|c|c|c|c|c|c|}
\hline \multirow{2}{*}{ Sl. No. } & \multirow{2}{*}{ Land use/land cover } & \multicolumn{2}{|c|}{ Area (ha) } & \multirow{2}{*}{$\begin{array}{l}\text { Difference } \\
\text { Area (ha) }\end{array}$} & \multirow{2}{*}{$\begin{array}{c}\text { Increase/decrease } \\
(\%)\end{array}$} & \multirow{2}{*}{$\begin{array}{c}\text { Annual rate of } \\
\text { increase or } \\
\text { decrease }(\%)\end{array}$} \\
\hline & & 1992 & 2014 & & & \\
\hline 1 & Dense primary forest & 22595.9 & 7480.71 & 15115.19 & -23.07 & -3.04 \\
\hline 2 & Secondary Forest & 22139.3 & 34952.7 & -12813.4 & 19.55 & 1.67 \\
\hline 3 & Grassland & 19122.8 & 21002.5 & -1879.7 & 2.87 & 0.45 \\
\hline 4 & Built-up & 992.25 & 1439.46 & -447.21 & -0.69 & 2.05 \\
\hline 5 & Water/River & 674.55 & 649.53 & 25.02 & -0.11 & -0.17 \\
\hline
\end{tabular}

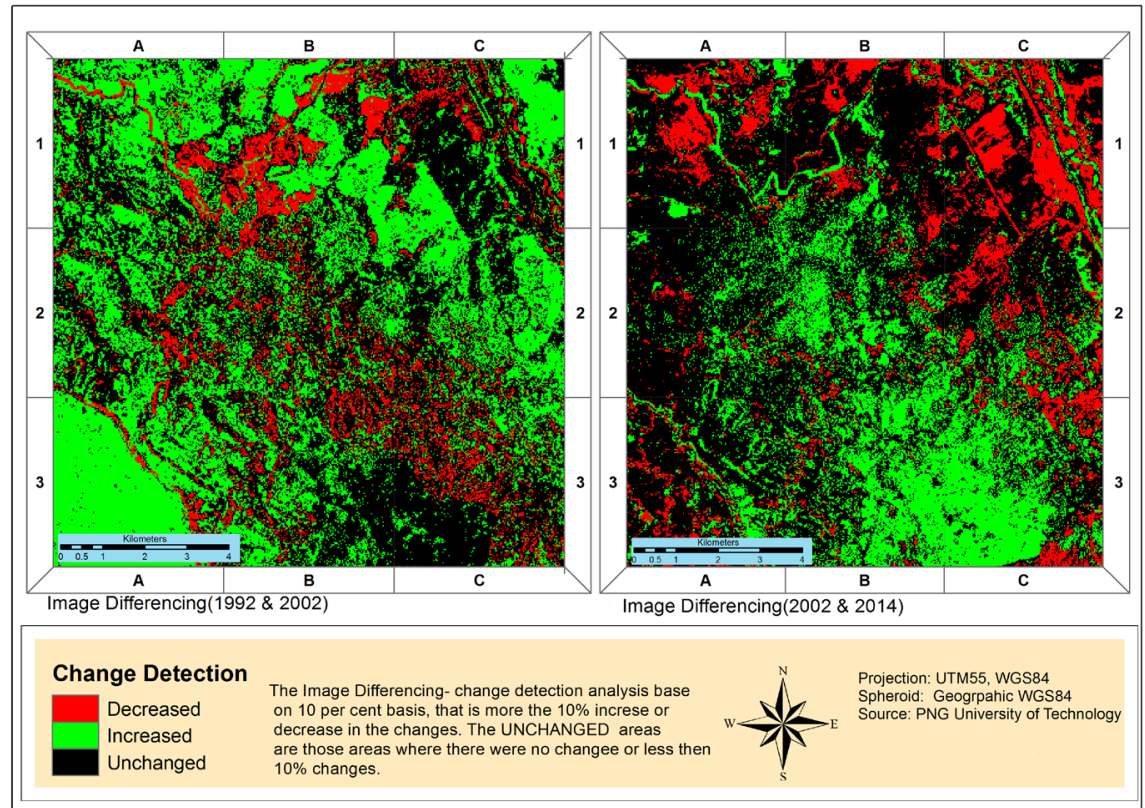

Figure 5. A graphical preview of change detection analysis through image differencing.

seen to be contributing meaningfully to the betterment of the lives of people, the majority of whom live in rural areas. The service functions of forests are increasingly becoming appreciated by communities' and forest owners and the Forest Industry company in Bulolo area. Eventually, some of the key service functions that threatened through conversion of the primary forests to gardens to feed the increasing rural populations, logging, and removal of primary forest for secondary forest by Bulolo Forest Products, and other land uses that remove forest cover and impact on forest habitat. These increases also are from forest clearance for road and other infrastructure development. The biggest treat is logging activities in and around Bulolo. The Bulolo forest products have converted a lot of primary forest to secondary forest for commercial purpose.

Deforestation is not an unstoppable or irreversible process. Increased and concerted efforts in forest plantation "rebirth" and rejuvenation will bring to use the type of forest reserve we envisaged. In order to reduce the effects of deforestation in Bulolo forest reserve the study has the followings as its recommendations, like 1) Bulolo district Government should be strict in preserving forest re- 
serves from illegal logging and forms of harm to the forest resources and the usage, 2) the promotion of alternative energy source for fire in order to reduce the pressure on the forest, 3 ) development and promotion of trade in non-timber forest product to reduce the pressure on timber resources and to enhance rural livelihood, 4) any form of forest plantation degradation should be stopped forthwith, having realized the purpose for which the reserve was meant for, 5) available vegetation area and the grassland must be converted into forest plantation of exotic fast growing species, 6) technology of remote sensing and GIS should be employed in major studies, concerning national issue such as forest resources monitoring and management, deforestation, reforestation etc. In the future research authors

In this study, we used medium resolution satellite data and the recent data set was of 2014 because of lack of proper funding. It is recommended that this type of research be used again to monitor forest resources, like canopy density and possible forest loss in Bulolo area using most recent and high resolution satellite data.

\section{Conflicts of Interest}

The authors declare no conflict of interest.

\section{References}

Bryan, J., Shearman, P., Ash, J., \& Kirkpatrick, J. B. (2010). Impact of Logging on Aboveground Biomass Stocks in Lowland Rain Forest (pp. 2096-2103). New Guinea: Ecological Society of America.

FAO (2005). Global Forest Review Assessment 2005. Papua New Guinea Country Report, Rome: FAO.

Fox, J. C., Yosi, C. K., Nimiago, P., Oavika, F., Pokana, N., Lavong, K., \& Keenan, R. J. (2010). Assessment of Aboveground Carbon in Primary and Selectively Harvested Tropical Forest in Papua New Guinea. Biotropica, 42, 410-419. https://doi.org/10.1111/j.1744-7429.2009.00617.x

Hammermaster, E. T., \& Saunders, J. C. (1995). Forest Resources and Vegetation Mapping of Papua New Guinea. Canberra: CSIRO.

Jensen, J. R. (1996). Introductory Digital Image Processing: A Remote Sensing Perspective (2nd Edition, pp. 197-279). Upper Saddle River: Prentice Hall.

Lamb, D. (1990). Exploiting the Tropical Rain Forest: An Account of Pulpwood Logging in Papua New Guinea. Man and Biosphere Series, Vol. 3, MAB/UNESCO Pub.

Lillesand, T. M., Kiefer, R. W., \& Chipman, J. W. (2008). Remote Sensing and Image Interpretation. In L. Kelleher (Ed.), USA: John Wiley \& Sons, Inc.

Ningal, T., Bregt, A., \& Hartemink, A. E. (2008). Land Use Change and Population Growth in the Morobe Province of Papua New Guinea between 1975 and 2000. Journal of Environmental Management, 87, 117-124.

https://doi.org/10.1016/j.jenvman.2007.01.006

Paijmans, K. (Ed.) (1976). New Guinea Vegetation. CSIRO and ANU, Canberra: Australian National University Press.

PNGFA (2004). Review of Current Logging Projects 2004. Individual Project Review Report No. 7 TP 2-14 Vailala Block 1. https://pngforests.com 
PNGRIS (2008). Papua New Guinea Resource Information System. The Land-Use Section, Science and Technology Branch (3rd ed.). Boroko: University of Papua New Guinea.

Samanta, S., \& Pal, D. K. (2016). Change Detection of Land Use and Land Cover over a Period of 20 Years in Papua New Guinea. Natural Science, 8, 138-151. https://doi.org/10.4236/ns.2016.83017

Samanta, S., Pal, D. K., Lohar, D., \& Pal, B. (2012). Interpolation of Climate Variable and Temperature Modeling. Theoretical and Applied Climatology, 107, 35-45. https://doi.org/10.1007/s00704-011-0455-3

Shearman, P. L., Ash, J., Mackey, B., Bryan, J. E., \& Lokes, B. (2009). Forest Conversion and Degradation in Papua New Guinea 1972-2002. Biotropica, 41, 379-390. https://doi.org/10.1111/j.1744-7429.2009.00495.x

Shearman, P. L., Bryan, J. E., Ash, J., Hunnam, P., Mackey, B., \& Lokes, B. (2008). The State of the Forests of Papua New Guinea. Mapping the Extent and Condition of Forest Cover and Measuring the Drivers of Forest Change in the Period 1972-2002. University of Papua New Guinea.

Yali, R. G., Samanta, S., \& Yosi, C. K. (2015). Improved Estimation of Forest Carbon (Biomass) Using Bi-Temporal Rapid Eye Data in a Low-Altitude Tropical Landscape. Melanesian Journal of Geomatics and Property Studies, 1, 22-39. 